\title{
The Influence of Husband-Wife Interaction and Parent-Child Interaction on Family Subjective Well-Being in KB and Non-KB Villages
}

\author{
Suciyati Martinea ${ }^{\left.1^{*}\right)}$, Euis Sunarti ${ }^{2}$ \\ ${ }^{1,2}$ Department of Family and Consumer Sciences, Faculty of Human Ecology, IPB University, \\ Bogor 16680, West Java, Indonesia
}

*) Corresponding author: suciyati_martinea@apps.ipb.ac.id

\begin{abstract}
Family subjective well-being is an evaluation of satisfaction related to physical-economic, social, and psychological aspects. This study discussed husband-wife interactions, parent-child interactions, and family subjective well-being in Pasirjaya Village. This study used a crosssectional design. This study involved 120 families who were selected by stratified random sampling by place of residence; Family planning participating village (KB village) and Family planning non-participating village (non-KB village) in KampungMuara, Pasirjaya Village, West Bogor. The results of the independent sample t-tests showed a higher average in KB village on husband-wife interactions (dimensions of love, directing, and respect) and parent-child interactions (dimension of directing). The results of the regression test showed a positive influence of the marriage duration and parent-child interactions but a negative influence of family size on family subjective well-being.
\end{abstract}

Keywords: husband-wife interaction, $\mathrm{KB}$ village, non-KB village, parent-child interaction, subjective well-being.

\begin{abstract}
Abstrak
Kesejahteraan subjektif keluarga merupakan suatu evaluasi kepuasan yang berkaitan dengan aspek fisik-ekonomi, sosial, dan psikologis. Penelitian ini bertujuan untuk menganalisis interaksi suami-istri, interaksi orang tua-anak, dan kesejahteraan subjektif keluarga di Kelurahan Pasirjaya. Penelitian ini menggunakan desain cross sectional melibatkan 120 keluarga utuh yang memiliki anak balita yang dipilih secara stratified disproportional random sampling menurut tempat tinggal (kampung Keluarga Berencana dan kampung non-Keluarga Berencana) di Kampung Muara, Kelurahan Pasirjaya, Bogor Barat. Hasil analisis menunjukkan terdapat korelasi positif antara kesejahteraan subjektif dengan interaksi suami-istri dan interaksi orang tua-anak. Hasil uji beda menujukkan rataan lebih tinggi di kampung KB pada interaksi suami-istri (dimensi cinta, arahan, dan menghargai) dan interaksi orang tua-anak (dimensi arahan). Hasil pada uji regresi menunjukkan bahwa kesejahteraan subjektif berpengaruh positif dengan lama pernikahan, interaksi orang tua-anak, akan tetapi berpengaruh negatif pada besar keluarga
\end{abstract}

Kata kunci: interaksi orang tua-anak, interaksi suami-istri, kampung $\mathrm{KB}$, kampung non-KB, kesejahteraan subjektif. 


\section{Introduction}

Indonesia is an archipelago country with a population that continues to grow every year. Based on United in terms of population which will cause a decline in the welfare of the nation (Badan Perencanaan Pembangunan Nasional, 2015). In the nation data, Indonesia ranks fourth in the world with the largest population after China, India, and the United States. The increase in population will certainly have an impact on the emergence of problems in Indonesia's welfare of the nation is built from the smallest component in society, namely a prosperous family. The family is the smallest unit in a society consisting of husband and wife, or husband, wife, and children, or father and child, or mother and child (Law No. 52 of 2009).

Family well-being consists of two approaches namely objective and subjective well-being. Objective well-being is measured based on the level of fulfillment of basic and developmental needs (Sunarti, 2013). Subjective well-being is a person's judgment about their lives in positive ways including cognitive assessment and affective reactions, such as happiness, satisfaction, morals, and positive influence (Diener, 1984). Subjective well-being is influenced by many factors in which these variables can influence people's ability to achieve their goals (Emmons, 1986). According to the Centers for Disease Control and Prevention (2018), well-being has a positive effect on a mutually supportive relationship, such as interaction. Family interaction consists of relationships that affect each other between husband and wife, parents and children, and children and children (Chuang, 2005). Family interaction can be seen as an indicator of how families organize themselves in carrying out activities that provide characteristics to survive in a group (Aldous, 1977).

Family Planning Program (Keluarga Berencana; KB) is one of the government programs that aim to reduce the rate of population growth, reduce childbirth and maternal mortality (Badan Perencanaan Pembangunan Nasional, 2015). KB Village is a villagelevel regional unit with certain criteria where there is a combination of Family Planning and Family Development Population (KKBPK) and related sector development to improve the quality of life of families and communities. The role of the family is very important in the development carried out by the government through the family planning program as a form of strengthening family resilience and becoming a prosperous family. A family with a higher level of well-being indicates a better quality of life so that in the end the family can create better conditions to keep improving their well-being (Rosni, 2017).

\section{Methods}

This study is part of the research project entitled "Internal Interaction and Family External Transactions on Child Development and Family Well-being". This research was carried out using a cross-sectional study design. This study used the interview method which was assisted by a questionnaire. The research location was Pasirjaya Village, West Bogor District, West Java. The research location was determined purposively by considering that the Pasirjaya Village is a part of 16 villages in the West Bogor Subdistrict whose population conditions are very heterogeneous and dense. The study site was divided into two regions, namely RW 11 (KB village) and RW 14 (non-KB village). The study was conducted in April 2018. The population in this study was all intact families with the criteria of the presence of husband, wife, and children under five. The samples 
in this study were 120 families. The sampling technique employed stratified disproportional random sampling because the number of population is uniform but not proportional.

The measures of family interaction were developed from Chuang (2005) which includes husband and wife interaction (20 statements), consist of dimensions of love, directing, domineering, hostility, and respect, with Cronbach's alpha of 0.779. Responses are rated as $0=$ never, $1=$ rarely, $2=$ often, and $3=$ always. Parent-child interaction consists of 11 statements with dimensions of love, directing, and domineering, with Cronbach's alpha of 0.663 . Responses are rated as $0=$ never, $1=$ rarely, $2=$ often, and $3=$ always. Subjective family well-being was developed from Sunarti's instrument (2001) consisting of physical-economic well-being, social well-being, and psychological well-being, with Cronbach's alpha of 0.903 (28 statements). Responses are rated as $0=$ dissatisfied, $1=$ quite satisfied, $2=$ satisfied, and $3=$ very satisfied.

Inference analysis that was used included independent sample t-test and regression test. The independent sample t-test was to analyze differences in husband-wife interactions, parent-child interactions, and subjective well-being between families in KB village and non-KB village. Multiple linear regression tests were performed to analyze the influence of family characteristics, husband-wife interactions, and parent-child interactions on subjective well-being.

\section{Results}

\section{Family Characteristics}

Data shows that the average age of husband and wife was in the early adult category, which is in the range of 18-40 years with older age in the KB family (Hurlock, 1980). The average higher education of husbands in KB village was 9.8 years (completed junior high school) and wife was 9.2 years (completed junior high school), with the lowest level of education not completing elementary school and the highest level of bachelor's degree. Families were included in the small family category ( $\leq 4$ people) with an average number of family members in the $\mathrm{KB}$ and non-KB villages being 4 people (Badan Kependudukan dan Keluarga Berencana Nasional, 2005). The Bogor City poverty line is Rp392,405 (Badan Pusat Statistik, 2015). The average income per capita of families in the KB village was Rp648,448 and the average in the non-KB village was Rp585,764. Thus, the average income per capita of the family in this study was Rp614,844 which indicates that $65 \%$ of families were categorized as not poor. The average length of the marriage was 10.4 years in KB village and 10.8 years in the non-KB village. The shortest marriage age was 2 years whereas the longest was 26 years. The number of children in the family ranged from 1-7 children with an average of three children in each family. The average length of stay of the family was around 19.13 years, with the shortest length of stay was one year, and the longest was 44 years.

\section{The Independent Sample T-Test of Husband-Wife Interactions, Parent-Child Interactions, and Subjective Well-being}

\section{Husband-Wife Interactions}

Table 1 shows husband-wife interactions in $\mathrm{KB}$ villages and non-KB villages were significantly different $(p<0.05)$. 
Table 1. The results of the independent sample t-test for husband and wife interactions of families in the KB and non-KB villages

\begin{tabular}{lcccr}
\hline Variable & Mean difference & KB village & Non-KB village & $p$-value \\
\hline Love (index) & 10.416 & 7.402 & 6.361 & $\mathbf{0 . 0 0 5 * *}$ \\
Directing (index) & 10.555 & 7.259 & 6.203 & $\mathbf{0 . 0 0 9 * *}$ \\
Domineering (index) & -2.111 & 1.966 & 2.177 & 0.450 \\
Hostility (index) & -2.916 & 1.847 & 5.888 & 0.339 \\
Respect (index) & 5.555 & 5.888 & 5.333 & $\mathbf{0 . 0 8 6}$ \\
\hline
\end{tabular}

Note. $(*)$ significant at $p<0.10,(* *)$ significant at $p<0.05$

\section{Parent-Child Interactions}

The results of the independent sample t-test on parent-child interaction as shown in Table 2 indicate that the $\mathrm{KB}$ villages had a significant difference compared to non-KB villages $(p<0.10)$.

Table 2. The results of the independent sample t-test for parent-child interactions of families in the KB and non-KB villages

\begin{tabular}{lcccr}
\hline Variable & Mean difference & KB & Non-KB & p-value \\
\hline Love (index) & 3.888 & 8.736 & 8.347 & 0.150 \\
Directing (index) & 4.629 & 8.648 & 8.185 & $\mathbf{0 . 0 9 7 *}$ \\
Domineering (index) & 1.666 & 3.305 & 3.138 & 0.587 \\
\hline
\end{tabular}

Note. $\left.{ }^{*}\right)$ significant at $p<0.10,(* *)$ significant at $p<0.05$

\section{Subjective Well-being}

The independent sample t-test results on subjective well-being shown in Table 3 indicate that the dimensions of subjective well-being of families in KB village and the non-KB village did not have a significant difference $(p>0.05)$.

Table 3. The results of the independent sample t-test for subjective well-being of families in $\mathrm{KB}$ and non-KB villages

\begin{tabular}{lcccr}
\hline Variable & Mean difference & KB & Non-KB & p-value \\
\hline Physical economy well-being (index) & -0.370 & 4.635 & 4.672 & 0.908 \\
Social well-being (index) & -3.444 & 5.244 & 5.588 & 0.321 \\
Psychology well-being (index) & 3.214 & 5.940 & 5.619 & 0.307 \\
\hline
\end{tabular}

Note. $\left(^{*}\right)$ significant at $p<0.10,(* *)$ significant at $p<0.05$

The Influence of Family Characteristics, Husband-Wife Interactions, and ParentChild Interactions on Subjective Well-being

The results of the regression model tested are shown in Table 4. The results of the first regression model showed that parent-child interaction had a significant positive effect on subjective well-being $(\beta=0.416)$. Each increase in parent-child interaction will increase subjective well-being with an Adjusted R Square value of 0.130. The results of the second regression model showed that family size significantly negatively influenced subjective well-being ( $\beta=-3.368)$. This shows that each increase in family size will reduce subjective well-being with an Adjusted R Square value of 0.152. The results also showed the marriage duration had a significant positive effect on the subjective well-being of the family $(\beta=0.462)$, indicating that each increase in marriage duration will reduce subjective well-being with an Adjusted R Square value of 0.152 . 
Table 4. Regression coefficients of family characteristics, husband-wife interactions, parent-child interactions, and subjective well-being

\begin{tabular}{|c|c|c|c|c|}
\hline & Variable & Unstandarized $(\beta)$ & Standarized $(\beta)$ & $p$-value \\
\hline \multirow{3}{*}{ Model 1} & Constant & 9.369 & & 0.350 \\
\hline & Husband-wife interaction & 0.158 & 0.125 & 0.204 \\
\hline & Parent-child interaction & 0.416 & 0.304 & $0.002 *$ \\
\hline & $\mathrm{F}$ & & & 9.916 \\
\hline & Adj. R Square & & & 0.130 \\
\hline & p-value & & & 0.000 \\
\hline \multirow{8}{*}{ Model 2} & Constant & 22.982 & & 0.060 \\
\hline & Length of husband's education & 0.770 & 0.156 & 0.138 \\
\hline & Length of wife's education & -0.809 & -0.149 & 0.159 \\
\hline & Duration of stay & 0.172 & 0.130 & 0.164 \\
\hline & Family size & -3.368 & -0277 & $0.015 *$ \\
\hline & Marriage duration & 0.462 & 0.185 & $0.081 *$ \\
\hline & Husband-wife interaction & 0.171 & 0.134 & 0.178 \\
\hline & Parent-child interaction & 0.318 & 0.233 & $0.023 *$ \\
\hline \multirow{4}{*}{\multicolumn{2}{|c|}{$\begin{array}{c}\mathrm{F} \\
\text { Adj. R Square } \\
p \text {-value }\end{array}$}} & & & 4.139 \\
\hline & & & & 0.152 \\
\hline & & & & 0.001 \\
\hline & & 22.704 & & 0.013 \\
\hline \multirow{6}{*}{ Model 3} & Love (Husband-wife) & 0.175 & 0.235 & $0.024 *$ \\
\hline & Directing (Husband-wife) & -0.141 & -0.208 & $0.072 *$ \\
\hline & Respect (Husband-wife) & 0.063 & 0.073 & 0.455 \\
\hline & Love (Parent-child) & 0.436 & 0.426 & $0.000 * *$ \\
\hline & Directing (Parent-child) & -0.107 & -0.108 & 0.276 \\
\hline & Domineering (Parent-child) & -0.113 & 0.125 & 0.138 \\
\hline & $\mathrm{F}$ & & & 6.456 \\
\hline & Adj. R Square & & & 0.216 \\
\hline & p-value & & & 0.000 \\
\hline \multirow{17}{*}{ Model 4} & Constant & 28.769 & & 0.023 \\
\hline & Husband's age & 0.214 & 0.103 & 0.366 \\
\hline & Length of husband's education & 0.550 & 0.111 & 0.296 \\
\hline & Length of wife's education & -0.616 & -0.113 & 0.269 \\
\hline & Duration of stay & 0.100 & 0.076 & 0.404 \\
\hline & Marriage duration & 0.258 & 0.103 & 0.434 \\
\hline & Family size & -5.301 & -0.436 & $0.019 *$ \\
\hline & Number of child & 2.635 & 0.199 & 0.303 \\
\hline & Love (Husband-wife) & 0.186 & 0.250 & 0.019* \\
\hline & Directing (Husband-wife) & -0.148 & -0.218 & $0.063 *$ \\
\hline & Respect (Husband-wife) & 0.078 & 0.091 & 0.365 \\
\hline & Love (Parent-child) & 0.411 & 0.402 & $0.000 * *$ \\
\hline & Directing (Parent-child) & -0.121 & -0.122 & 0.217 \\
\hline & Domineering (Parent-child) & -0.068 & 0.076 & 0.375 \\
\hline & $\mathrm{F}$ & & & 3.875 \\
\hline & Adj. R Square & & & 0.238 \\
\hline & $p$-value & & & 0.000 \\
\hline
\end{tabular}

Note. $(*)$ significant at $p<0.10,(* *)$ significant at $p<0.05$

The results of the third regression model showed that the dimensions of love in husband-wife interactions had a significant positive effect on subjective well-being $(\beta=0.175)$. Every increase in the love aspect will increase subjective well-being with the value of Adjusted R Square of 0.216. The results also showed the dimension of directing on husband-wife interaction significantly negatively affected the subjective well-being of the family ( $\beta=-1.141)$. This shows that each increase in directing aspect in the interaction 
will reduce subjective well-being with Adjusted R Square value of 0.216. The results of regression tests showed that the dimension of love on parent-child interactions had a significant positive effect on subjective well-being $(\beta=0.436)$. This shows that each increase in love aspect will increase the family subjective well-being with Adjusted $\mathrm{R}$ Square 0.216. Overall, the Adjusted R Square value indicates that this model only explained $21.6 \%$ of the effects of the independent variables on subjective well-being while the remaining $78.4 \%$ was influenced by other variables not examined in the study.

The results of the fourth regression model showed that family size significantly negatively influenced subjective well-being ( $\beta=-5.301)$. This shows that each increase in family size will reduce subjective well-being with an Adjusted R Square value of 0.238. Other results also showed that the dimension of love in husband-wife interactions had a significant positive effect on subjective well-being $(\beta=0.186)$. Every increase in the love aspect will increase subjective well-being with an Adjusted R Square value of 0.238. In the fourth model, it can also be seen that the dimension of directing in husband-wife interaction had a significant negative effect on subjective well-being $(\beta=-0.148)$, indicating that each increase in the directing aspect will reduce subjective well-being with Adjusted R Square value of 0.238 . In parent-child interaction the dimension of love had a significant positive effect on family well-being ( $\beta=0.411)$, meaning that each increase in love aspect will increase subjective well-being with an Adjusted R Square value of 0.238. Overall, the Adjusted R Square value indicates that the fourth model only explained $23.8 \%$ of the effects of the independent variables while the rest was influenced by other variables not examined in the study.

\section{Discussion}

Subjective well-being is a direct evaluation in the process of each individual in assuming that aspects of their lives have important reasons to be assessed (Webb \& Herrera, 2012). Subjective well-being is often used as an indicator in assessing one's life satisfaction (Diener, Scollon, \& Lucas, 2009). Someone who is often happy and not too often experiences negative emotions (anger and sadness) will experience more life satisfaction and will have better subjective well-being. Conversely, someone who is said to be unhappy or has little affection and happiness, that person will feel dissatisfaction in his life so that his subjective well-being is low (Utami, 2009). In the study of Sunarti (2001), subjective well-being consists of (1) physical-economic well-being; (2) social well-being; and (3) psychological well-being.

The results showed that the subjective well-being of families living in Pasirjaya Village was in the moderate category. In the dimensions of physical-economic wellbeing, there was an item question with the lowest average index, namely savings owned by the family. This result is in line with research by Asmoro (2016) and Ilmi (2016), where the savings owned by the family get the lowest achievement in the subjective wellbeing. This condition shows that there are indeed many families who have not been able to set aside their money to save (out of 120 families studied, only 47 families have savings). The parents also stated that it was still difficult to get used to saving. According to Syarifuddin (2012), if someone wants successful financial planning, then there needs to be realistic and flexible financial management. The social well-being dimension shows that the families in this study were not satisfied with their relationship with the surrounding environment. Ross (2000) found that problematic neighbors/problematic environments will affect depression in adults. Respondents also said that they were more 
satisfied to spend time with family members compared to their neighbors. On the psychological well-being dimension, more than half of the families were satisfied with being Muslim. Ellison's research (1991) states that there is a direct positive effect on the religious beliefs held by a person towards a higher level of life satisfaction. Individuals with strong religious beliefs have a higher level of satisfaction and happiness in life.

Husband and wife interaction is a mutual relationship between husband and wife that shows a process of mutual influence. Families have interactions and relationships that provide a bond that is far longer than with other groups. The interaction of husband and wife is conceptualized into three basic components, namely suitability in role perception, role reciprocity, and equality of role functions (Saxton, 1990 in Puspitawati, 2012). The results showed that husband and wife interactions were in the medium category. The results showed the highest average index was found in the dimensions of love that were described by husband and wife helping each other when there were problems, expressing their feelings to each other, and finding time to interact with each other. This result is following the research of Hendrick, Hendrick, and Adler (1988) that love is one of the important factors in relationship satisfaction. A successful marital adjustment can be supported by factors of mutual giving and receiving love, expression of affection, mutual respect, and mutual openness between husband and wife (Anjanie, 2006).

Parent-child interaction is a mutual interaction between parent and child. The relationships contained in it relate to various dimensions, such as love, authority, dependency, and in a variety of interactions involving care, control, instruction, and assistance (Puspitawati, 2012). The results also showed the highest average index found in the dimensions of love. On the item love, parent interaction with children was of high category, this shows that parents express attention to children, immediately approach the child when crying, feel happy to care for children, and interact with children. This is according to what Sunarti (2013) noted that the way parents interact with children, some of which is through a sense of mutual acceptance, mutual understanding, mutual trust, showing concern, empathy, and sympathy.

The results of the independent sample t-test on the husband-wife interaction show that the dimensions of mastery and contention did not have a significant difference between the $\mathrm{KB}$ and non-KB villages. This is alleged because in marriage there will always be things that are not desirable so that couples fight or want to dominate the other party. Problems in the household often occur and have become a part of the twists and turns of household life that may lead to divorce (Matondang, 2014). The difficulty of a husband and wife to adjust marriages is also caused by changing human characteristics. Many things need to be adjusted in marriage, including religion or values, household affairs, nurture, financial problems, sexual relations issues, social activities and recreation, relationships with family, and relationships with friends (Wahyuningsih, 2002). However, the dimensions of love, direction, and respect have a significant difference between $\mathrm{KB}$ and non-KB villages, with the highest average in $\mathrm{KB}$ villages. According to data obtained by wife, the education level in $\mathrm{KB}$ village was higher than that in non-KB villages. Meliani, Sunarti, and Krisnatuti (2014) found that wife's education has a positive effect on marital satisfaction, in which the higher the education of an individual, the more clear his/her insight; thus, his/her perception of himself/herself and his/her marriage life gets better. Marriage satisfaction is based on love or expression of love for the couple from time to time (Nurani, 2004). Other data obtained is about the age of the wife in which wives in $\mathrm{KB}$ village were more mature than those in the non-KB 
village. More mature wives may indicate, even though not necessarily, that they have more experience and knowledge so that the implementation of family development tasks can run optimally and affect satisfaction in marriage (Tyas, Herawati, \& Sunarti, 2017).

The independent sample t-test results on parent-child interaction show that the dimensions of love and mastery did not have a significant difference between the KB and non-KB villages. This is alleged because, in infancy, parents give attention and care to their children beyond other age groups. Infancy is a phase when the basic form of human personality, sensing abilities, thinking, skills, language and speech, and social behavior are occurred (Yulita, 2014). Therefore, toddlers are a separate group whose growth and development requires more special attention. This is also in line with Erawati's research (2014) which states that there is a relationship between the functions/attention given by parents to children as they enter toddlerhood. However, the referral dimension has a significant difference between $\mathrm{KB}$ and non-KB villages, with the highest average in $\mathrm{KB}$ villages. Parents have directed their children about good or bad behavior in their daily interactions. According to data obtained, the education of parents in the KB village was higher than that in the non-KB village. The research results of Alexander, Entwisle, and Bedinger (1994) found that parents who have an educational background have higher trust and expectations about their children's abilities compared to parents who have a low educational background. Eccles's research results (1993) also showed that parental education influences parents' beliefs and behavior in directing children towards more positive goals.

The independent sample t-test results on subjective well-being on the three dimensions (physical-economic, social, and psychological dimensions) did not have significant differences between the $\mathrm{KB}$ and non-KB villages. In the physical-economic dimension, according to per capita income, Pasirjaya Village is classified as not poor with an average of Rp614,844. The results of Srisusanti and Zulkaida's (2013)research noted that higher incomes may increase the standard of living and their needs as well. Yohanna and Maya (2018) also said that the behavior of Indonesian people tends to be consumptive at present, which is why families find it difficult to manage family finances. In the social dimension in the $\mathrm{KB}$ and non-KB villages, there was no difference, mentioned in the discussion about parent-child interaction that respondents are more satisfied to spend time with family than interacting with outside communities. Maryanti (2016) stated that families with children under five are reluctant to participate in association activities because they are more focused on taking care of children and families. Families with children under five tend to spend more time in the house to take care of their children, so families are less active in participating and engaging in social activities with the environment (Syahidah, 2018). On the psychological dimension, discussing the feeling of security felt by families in carrying out their daily lives, the average respondent said that they were worried about their surroundings. According to Unger and Wandersman (1985) said that there is a belief that neighbors and the environment are the people who have the highest responsibility in one's life.

Regression test results indicate that family size had a significant negative effect on subjective well-being. This is in line with research by Muflikhari (2010) and Widyaningsih and Muflikhati (2015) which stated that family well-being is influenced by family size, where families with fewer members have greater opportunities for prosperity compared to families with more members. The research of Rizkillah, Sunarti, and Herawati (2015) also showed that the number of family members had a significant negative effect on the quality of the caregiving environment related to marital satisfaction 
and happiness. Sunarti's research (2015) is also in line with this study that family size negatively affected family well-being, but the results of this study are inversely proportional to the research of Puspitawati (2009) and Zuliany (2013) that one of the factors positively influencing subjective well-being is a big family. Other results indicate that the marriage duration had a significant positive effect on subjective well-being. This is in line with the research of Meliani et al. (2014) which shows that marriage duration has a positive effect on marital satisfaction. This explains that the longer the marriage lasts, the higher the satisfaction in marriage and later affects the subjective well-being of the family.

Regression test results indicate the influence of parent-child interaction on subjective well-being. According to Shvedovskaya and Archakova (2015), a child is an active partner, has his motives, and is guided by the mental representation of parents and the interaction between the two. The research of Casas et al. (2008) also proved that the interaction between parents and children affects the well-being of one's life. This is in line with the study of Kohler, Behrman, and Skytthe (2005) that having a child can affect one's well-being. The results of the regression test on the dimensions of love in conjugal interactions had a significant positive effect on subjective well-being. This is in line with the research of Rambe (2015) that the interaction between husband and wife can affect subjective well-being. Rubin (1970) said that love/affection is one of the factors that influence family interaction which results in satisfaction in a marriage. Some factors of love/affection in conjugal relationships are expressing affection verbally, showing physical affection, giving support and expressing things they like, helping each other, positive feelings such as happiness and feeling safe, intimate closeness, and accept negative things that are owned by each partner (Aldous, 1977). Sunarti (2013) said that the pattern of husband-wife interaction needs to be based on love and affection, empathy, mutual respect, openness, honesty, and accepting the partner as is. Good interaction between husband and wife will bring happiness, harmony, satisfaction, lasting marriage, and a good example for children. The dimension of love in parent-child interaction also has a significant influence on subjective well-being. The results of Chuang's research (2005) prove that there is a positive influence on the dimensions of love between family members, namely on the interaction of parents to their children and it affects the love/affection between interactions on the husband to his wife. Carr et al. (2014) also showed that the quality of marriage is very closely related to the evaluation of one's life as a whole and the feeling of happiness when carrying out daily activities. This shows that there is an influence between the dimensions of love with harmony and family wellbeing.

Regression test results show that the dimensions of referrals (husband and wife interaction) had a significant negative effect on subjective well-being. Bosse et al. (2013) stated that each group member has an autonomous neurological process, that is, personal mental states such as emotions, beliefs, and intentions, which may be difficult to combine in a group. Each family also has a unique ideology, background, values, communication patterns, roles and responsibilities that are different (Hamilton \& Catterall, 2008). The results of the study by Stets and Good (1990) showed that in husband-wife interactions women do more control/direction than men. Men tend to prefer to do things of their desires because they exercise control in a wider environment. This control is predicted to cause mild scale aggression in the interaction of both. This means that the direction given by the husband or wife when interacting can cause a negative influence when one partner directs or reprimands the tasks or things done by their spouse. 


\section{Conclusion and Recommendation}

\section{Conclusion}

The study results of families in Pasirjaya show that the average age of the husband is 36 years and the wife is 31 years old with an average length of education of 9.8 years (husband) and 9.2 years (wife). Large families are included in the small category with $(\leq 4)$ with an average of 4 people. The average length of the family marriage is almost 11 years, with an average length of stay reaching 19 years. There are 1-7 children in the family. Monthly per capita income of the family is above the poverty line of Bogor City with the lowest income of Rp80,000 and the highest income is Rp3,000,000.

The results of the Independent sample t-test on husband-wife and parent-child interactions show significant differences between $\mathrm{KB}$ villages and non-KB villages with the highest average in KB villages. Regression test results showed an influence of parentchild interaction on subjective well-being. The regression test results also showed that family size had a significant negative effect on subjective well-being. The marriage duration had a positive influence on subjective well-being. The dimension of love on husband-wife and parent-child interactions had a positive influence on subjective wellbeing while the direction dimension on child-husband and wife interaction had a negative influence on subjective well-being.

\section{Recommendation}

Based on the results of the study, the recommendations are as follows: (1) families, especially married couples are expected to realize that mutual respect is important in building harmony within the family to improve the subjective well-being of the family, (2) future research may want to examine the subjective well-being of families regarding its relation to external interactions other than family, (3) NGOs may find the results of this study useful as a reference in making programs that improve the subjective well-being of families in Pasirjaya Village, especially regarding the participation of families with children under five, and (4) Bogor regional government may evaluate the formation of the $\mathrm{KB}$ village or non-KB village program to improve the knowledge and abilities of parents related to the process of interaction in the family and well-being.

\section{References}

Aldous, J. (1977). Family interaction patterns. Annual Review of Sociology, 3, 105-135. http://dx.doi.org/10.1146/annurev.so.03.080177.000541

Alexander, K. L., Entwisle, D. R., \& Bedinger, S. D. (1994). When expectations work: Race and socioeconomic differences in school performance. Social Psychology Quarterly, 283-299. http://dx.doi.org/10.2307/2787156

Anjanie, C. (2006). Pola penyesuaian perkawinan pada periode awal (Doctoral dissertation, Airlangga University, Surabaya, Indonesia). Retrieved from http://repository.unair.ac.id /26593/

Asmoro, G.W. (2016). Kepadatan, tekanan sosial, tekanan psikologis, dan kesejahteraan subjektif keluarga yang tinggal di rumah susun Jatinegara Barat (Undergraduate thesis, IPB University, Bogor, Indonesia). Retrieved from https://repository.ipb.ac.id/handle/123456789/85057 
Bosse, T., Hoogendoorn, M., Klein, M. C., Treur, J., Van Der Wal, C. N., \& Van Wissen, A. (2013). Modelling collective decision making in groups and crowds: Integrating social contagion and interacting emotions, beliefs and intentions. Autonomous Agents and Multi-Agent Systems, 27(1), 52-84. http://dx.doi.org/10.1007/s10458-012-9201-1

Badan Kependudukan dan Keluarga Berencana Nasional. (2005). Keluarga Berencana dan Kesehatan Reproduksi. Retrieved from. https://www.bkkbn.go.id

Badan Perencanaan Pembangunan Nasional. (2015). Sumber Daya Manusia dan Kebudayaan: Indikator Kesejahteraan. Retrieved from http://www.bappenas.go.id

Badan Pusat Statistik. (2015). Jumlah dan Persentase Penduduk Miskin, Garis Kemiskinan, Indeks Kedalaman dan Indeks Keparahan Kemiskinan 2012-2015. Retrieved from https://bogorkota.bps.go.id/statictable/2018/05/14/94/jumlahdan-persentase-penduduk-miskin-garis-kemiskinan-indeks-kedalaman-danindeks-keparahan-kemiskinan-2012-2015.html

Carr, D., Freedman, V. A., Cornman, J. C., \& Schwarz, N. (2014). Happy marriage, happy life? Marital quality and subjective well-being in later life. Journal of Marriage and Family, 76(5), 930-948. http://dx.doi.org/10.1111/jomf.12133

Casas, F. E. R. R. A. N., Coenders, G., Cummins, R. A., González, M., Figuer, C., \& Malo, S. (2008). Does subjective well-being show a relationship between parents and their children?. Journal of Happiness Studies,9(2), 197-205. http://dx.doi.org/10.1007/s10902-007-9044-7

Chuang, Y. C. (2005). Effects of interaction pattern on family harmony and well-being: test of interpersonal theory, Relational-Models theory, and Confucian ethics. Asian Journal of Social Psychology, 8(3), 272-291. http://dx.doi.org/10.1111/j.1467-839X.2005.00174.x

Diener, E. (1984). Subjective well-being. Psychological Bulletin,95(3), 542. http://dx.doi.org/10.1037/0033-2909.95.3.542

Diener, E., Scollon, C. N., \& Lucas, R. E. (2009). The evolving concept of subjective well-being: The multifaceted nature of happiness. In Assessing Well-being (pp. 67-100). Springer, Dordrecht. http://dx.doi.org/10.1016/S1566-3124(03)15007-9

Eccles, J. S. (1993). School and family effects on the ontogeny of children's interests, self-perceptions, and activity choice. In J. Jacobs (Ed.), Nebraska Symposium on Motivation: Vol. 40. Developmental perspectives on motivation (pp. 145-208): Lincoln: University of Nebraska Press.

Ellison, C. G. (1991). Religious involvement and subjective well-being. Journal of Health and Social Behavior, 80-99. http://dx.doi.org/10.2307/2136801

Emmons, R. A. (1986). Personal strivings: an approach to personality and subjective wellbeing. Journal of Personality and Social Psychology,51(5), 1058. http://dx.doi.org/10.1037/0022-3514.51.5.1058

Erawati. (2014). Hubungan fungsi afektif keluarga dengan perkembangan balita di Desa Panduman Kecamatan Jelbuk Kabupaten Jember (Undergraduate thesis, Universitas Jember, Indonesia). Retrieved from http://repository.unej.ac.id/bitstream/handle/123456789/60528/Erawati\%20$\% 20092310101045 \_1 . p d f$ ?sequence $=1$

Hamilton, K. L., \& Catterall, M. (2008). Cooperation and conflict in family decision. European Advances in Consumer Research, 8, 45-47

Hurlock, E. B. (1980). Psikologi Perkembangan (5th ed.). Jakarta: Erlangga. 
Hendrick, S. S., Hendrick, C., \& Adler, N. L. (1988). Romantic relationships: love, satisfaction, and staying together. Journal of Personality and Social Psychology, 54(6), 980. http://dx.doi.org/10.1037/0022-3514.54.6.980

Ilmi, N. (2016). Kesesakan, iritabilitas, agresivitas dan kesejahteraan subjektif keluarga yang tinggal di rumah susun Jatinegara Barat (Undergraduate thesis, IPB University, Bogor, Indonesia). Retrieved from https://repository.ipb.ac.id/handle/123456789/84956

Kohler, H. P., Behrman, J. R., \& Skytthe, A. (2005). Partner+children=happiness? The effects of partnerships and fertility on well-being. Population and Development Review, 31(3), 407-445. http://dx.doi.org/10.1111/j.1728-4457.2005.00078.x

Maryanti. (2016). Modal sosial, dukungan sosial, dan ketahanan sosial keluarga di Rusunawa Jatinegara Barat (Undergraduate thesis, IPB University, Bogor, Indonesia). Retrieved from https://repository.ipb.ac.id/handle/123456789/84985

Matondang, A. (2014). Faktor-faktor yang mengakibatkan perceraian dalam perkawinan. JPPUMA Jurnal Ilmu Pemerintahan dan Sosial Politik Universitas Medan Area, 2(2), 141-150. http://dx.doi.org/10.31289/jppuma.v2i2.919

Meliani, F., Sunarti, E., \& Krisnatuti, D. (2014). Faktor demografi, konflik kerjakeluarga, dan kepuasan perkawinan istri bekerja. Jurnal Ilmu Keluarga \& Konsumen, 7(3), 133-142. http://dx.doi.org/10.24156/jikk.2014.7.3.133

Muflikhati, I. (2010). Analisis dan pengembangan model peningkatan kualitas sumberdaya manusia dan kesejahteraan keluarga di wilayah pesisir Provinsi Jawa Barat (Doctoral dissertation, IPB University, Bogor, Indonesia).Retrieved fromhttps://repository.ipb.ac.id/jspui/bitstream/123456789/55063/10/Cover.pdf

Nurani, A. S. (2004). Pengaruh kualitas perkawinan, pengasuhan anak dan kecerdasan emosional terhadap prestasi belajar anak (Undergraduate thesis, IPB University, Bogor, Indonesia). Retrieved from https://repository.ipb.ac.id/handle/123456789/6901

Puspitawati, H. (2009). Pengaruh nilai ekonomi pekerjaan ibu rumah tangga terhadap kesejahteraan keluarga subyektif. Jurnal Ilmu Keluarga \& Konsumen, 2(1), 1120. http://dx.doi.org/10.24156/jikk.2009.2.1.11

Puspitawati, H. (2012). Gender dan Keluarga: Konsep dan Realita di Indonesia. Bogor: IPB Press.

Rambe, Y. (2015). Pengaruh interaksi dan pola pengambilan keputusan keluarga terhadap kesejahteraan subjektif keluarga suami-istri bekerja (Undergraduate thesis, IPB University, Bogor, Indonesia). Retrieved from https://repository.ipb.ac.id/handle/123456789/83087

Republic of Indonesia Law No. 52 of 2009 on Population Development and Family Development.

Rizkillah, R., Sunarti, E., \& Herawati, T. (2015). Kualitas perkawinan dan lingkungan pengasuhan pada keluarga dengan suami istri bekerja. Jurnal Ilmu Keluarga \& Konsumen, 8(1), 10-19. http://dx.doi.org/10.24156/jikk.2015.8.1.10

Rosni, R. (2017). Analisis tingkat kesejahteraan masyarakat nelayan di desa dahari selebar kecamatan talawi kabupaten batubara. Jurnal Geografi, 9(1), 53-66. http://dx.doi.org/10.24114/jg.v9i1.6038

Ross, C. E. (2000). Neighborhood disadvantage and adult depression. Journal of Health and Social Behavior, 41(2), 177-187. http://dx.doi.org/10.2307/2676304

Rubin, Z. (1970). Measurement of romantic love. Journal of Personality and Social Psychology, 16(2), 265-273. http://dx.doi.org/10.1037/h0029841 
Srisusanti, S., \& Zulkaida, A. (2013). Studi deskriptif mengenai faktor-faktor yang mempengaruhi kepuasan perkawinan pada istri. UG Jurnal, 1(1), 133-141. http://dx.doi.org/10.13140/RG.2.2.30630.32324

Sunarti, E. (2001). Studi ketahanan keluarga dan ukurannya: telaah kasus pengaruhnya terhadap kualitas kehamilan (Doctoral dissertation, IPB University, Bogor, Indonesia). Retrieved from https://repository.ipb.ac.id/handle/123456789/4337

Sunarti, E. (2013). Ketahanan Keluarga: Penjelasan Materi Family Kit. Bogor: IPB Press.

Sunarti, E. (2015). Ketahanan Keluarga Indonesia: Dari Kebijakan dan Penelitian Menuju Tindakan. Bogor: IPB Press.

Shvedovskaya, A. A., \& Archakova, T. O. (2015). Styles of parent-child interactions in families with preschool-age children. Psychology in Russia, 8(2), 36. http://dx.doi.org/10.11621/pir.2015.0204

Stets, J. E., \& Pirog-Good, M. A. (1990). Interpersonal control and courtship aggression. Journal of Social and Personal Relationships, 7(3), 371-394. http://dx.doi.org/10.1177/0265407590073005

Syahidah, L. (2018). Pengaruh pengambilan keputusan dan nilai transaksi keluarga dengan lingkungannya terhadap ketahanan sosial keluarga (Undergraduate thesis, IPB University, Bogor, Indonesia). Retrieved from https://repository.ipb.ac.id/handle/123456789/95142

Syarifuddin, H. (2012). Analisis manajemen keuangan, tekanan ekonomi, strategi koping dan tingkat kesejahteraan keluarga nelayan di Desa Cikahuripan, Kecamatan Cisolok, Kabupaten Sukabumi (Undergraduate thesis, IPB University, Bogor, Indonesia). Retrieved fromhttps://repository.ipb.ac.id/handle/123456789/54401

Tyas, F. P. S., Herawati, T., \& Sunarti, E. (2017). Tugas perkembangan keluarga dan kepuasan pernikahan pada pasangan menikah usia muda. Jurnal Ilmu Keluarga \& Konsumen, 10(2), 83-94. http://dx.doi.org/10.24156/jikk.2017.10.2.83

Unger, D. G., \& Wandersman, A. (1985). The importance of neighbors: The social, cognitive, and affective components of neighboring. American Journal of Community Psychology, 13(2), 139-169. http://dx.doi.org/10.1007/bf00905726

Utami, M. S. (2009). Keterlibatan dalam kegiatan dan kesejahteraan subjektif mahasiswa. Jurnal Psikologi, 36(2),

144-163. http://dx.doi.org/10.22146/JPSI.7892

Wahyuningsih, H. (2002). Perkawinan: Arti penting, pola dan tipe penyesuaian antar pasangan. Psikologika: Jurnal Pemikiran dan Penelitian Psikologi, 7, 14. http://dx.doi.org/10.20885/psikologika.vol7.iss14.art2

Webb, D., \& Wills-Herrera, E. (Eds.). (2012). Subjective Well-Being and Security (Vol. 46). Dordrecht: Springer Netherlands. http://dx.doi.org/10.1007/978-94-0072278-1

Widyaningsih, E., \& Muflikhati, I. (2015). Alokasi pengeluaran dan tingkat kesejahteraan keluarga pada keluarga nelayan Bagan. Jurnal Ilmu Keluarga \& Konsumen, 8(3), 182-192. http://dx.doi.org/10.24156/jikk.2015.8.3.182

Yohanna, L., \& Maya, S. (2018). Upaya peningkatan kesejahteraan keluarga melalui pelatihan manajemen keuangan keluarga. Proceeding of Community Development, 1, 25-30.

Yulita, R. (2014). Hubungan Pola Asuh Orang Tua terhadap Perkembangan Anak Balita di Posyandu Sakura Ciputat Timur (Undergraduate thesis, Universitas Islam Negeri Syarif Hidayatullah, Jakarta, Indonesia). Retrieved from 
http://repository.uinjkt.ac.id/dspace/bitstream/123456789/25651/1/Refi\%20Yul ita\%20-\%20fkik.pdf

Zuliany, A. (2013). Peran istri dalam pengelolaan sumberdaya keluarga dan kesejahteraan subyektif keluarga nelayan pada sistem matrilineal (Undergraduate thesis, IPB University, Bogor, Indonesia). Retrieved from https://repository.ipb.ac.id/handle/123456789/63100 